
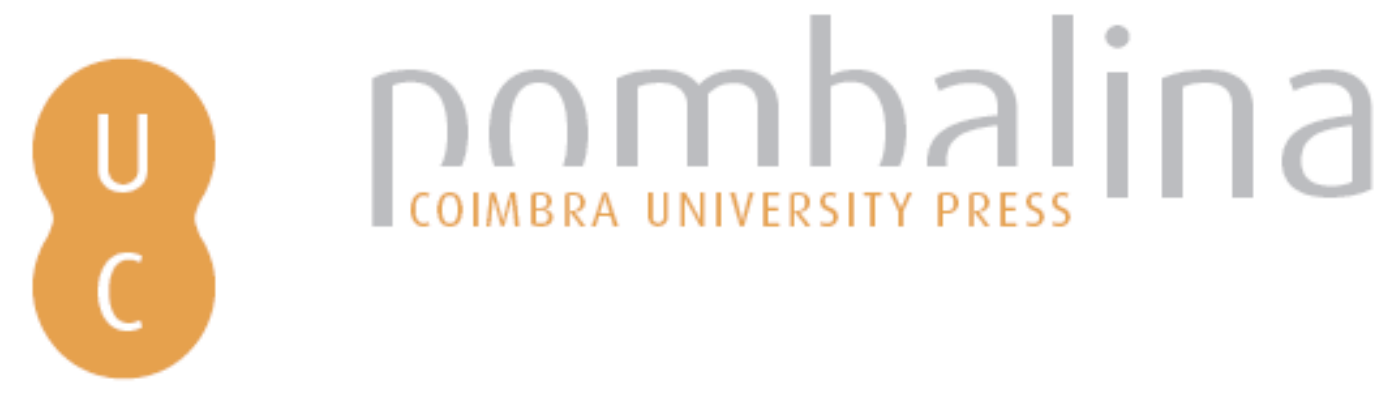

\title{
Modeling the productivity of forest fire suppression operations using production functions: a methodological approach
}

\author{
Autor(es): $\quad$ Rodríguez y Silva, Francisco; Hand, Michael \\ Publicado por: Imprensa da Universidade de Coimbra \\ URL \\ persistente: URI:http://hdl.handle.net/10316.2/44645 \\ DOI: $\quad$ DOI:https://doi.org/10.14195/978-989-26-16-506_128 \\ Accessed : $\quad$ 26-Apr-2023 11:16:53
}

A navegação consulta e descarregamento dos títulos inseridos nas Bibliotecas Digitais UC Digitalis, UC Pombalina e UC Impactum, pressupõem a aceitação plena e sem reservas dos Termos e Condições de Uso destas Bibliotecas Digitais, disponíveis em https://digitalis.uc.pt/pt-pt/termos.

Conforme exposto nos referidos Termos e Condições de Uso, o descarregamento de títulos de acesso restrito requer uma licença válida de autorização devendo o utilizador aceder ao(s) documento(s) a partir de um endereço de IP da instituição detentora da supramencionada licença.

Ao utilizador é apenas permitido o descarregamento para uso pessoal, pelo que o emprego do(s) título(s) descarregado(s) para outro fim, designadamente comercial, carece de autorização do respetivo autor ou editor da obra.

Na medida em que todas as obras da UC Digitalis se encontram protegidas pelo Código do Direito de Autor e Direitos Conexos e demais legislação aplicável, toda a cópia, parcial ou total, deste documento, nos casos em que é legalmente admitida, deverá conter ou fazer-se acompanhar por este aviso.

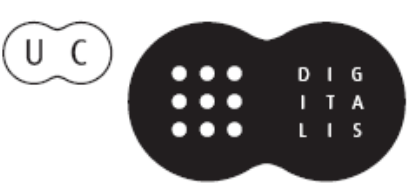




\section{ADVANCES IN}

\section{FOREST FIRE RESEARCH}

\section{8}

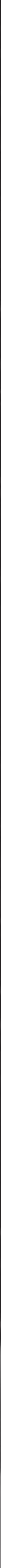




\title{
Modeling the productivity of forest fire suppression operations using production functions. A methodological approach
}

\author{
Francisco Rodríguez y Silva*1 ${ }^{1}$, Michael Hand ${ }^{2}$ \\ ${ }^{1}$ Forest Fire Laboratory. University of Córdoba (Spain), Edificio Leonardo da Vinci, Campus de \\ Rabanales, 14071, Córdoba, Spain. \{irlrosif@uco.es*\} \\ ${ }^{2}$ USDA Forest Service, Rocky Mountain Research Station. 201 14th St., SW. Washington, DC \\ 20024,USA. \{mshand@fs.fed.us\}
}

\begin{abstract}
Society, forest landscapes and fires constitute a triangle of interaction with important requirements and consequences. These interdependencies offer a field for the application and development of research with a clear focus on social sciences, in which the fire prevetion, risk analysis and socio-economic conditions are shaped as basic pillars.

Environmental dryness, climate and the consequences of fire exclusion, aggravated by urban growth in forest areas, with absence of preventive norms and under a scenario of high forest fires risk creates an environment susceptible to large forest fires that can affect the well-being of citizens. In this sense, the authorities and goverment are commiting large budgetary investments for the prevention and suppression of wildfires.

The knowledge advances of the dynamics of fire behavior have allowed to dimension the expansive capacity of fire and, as a function of it, to identify a priori the potential impacts. In this sense, the integration of this knowledge together with social and economic aspects, have allowed us to advance in the studies of costs and benefits, spatial-temporal determination of risks in probabilistic terms and others such as the evaluation of the fire severity, the operational strategy, the reduction of uncertainty and the help in the decision making process.

The present work explores the development of a methodology to incorporate fire suppression experience, detailed historical data on forest fire management from Mediterranean ecosystems, and empirical models to analyze efficiency and production. The resulting models of wildfire suppression production provides a basis for generating a conceptual framwork to study suppression operations.

The development of decision support tools based on econometric models of fire suppression production functions requires the selection of variables that define and determine the problem. The present work includes the main methodological considerations for the definition and development of an econometric model based on the study of efficiency and productivity through the development of production functions that can predict the operational suppression yields in different scenarios of forest fires (meters per hour of fire spreading containment and suppression). The resulting model may represent an opportunity to aid in the development of suppression operations plans, helping the fire managers determine the production rates of the resources dispatched to fire suppression.
\end{abstract}

Keywords: Suppressions operations, production function, econometric models, fire weather danger, production rates, suppression costs, ground resources, aerial resources, suppression difficulty index

The views expressed in this paper are the authors' and do not necessarily reflect those of the U.S. Department of Agriculture or the USDA Forest Service. Results are preliminary and subject to revision.

\section{Introduction}

The main lines of research developed from the middle of the first quarter of the twentieth century to the present, have allowed us to conceptualize the problem of the occurrence of forest fires, not only in physical, ecological, landscape management or operations suppression terms, but also the knowledge acquired due to the science associated with the study of forest fires, they define a new 
dimension with a very clear socio-economic perspective. On the other hand, the envelope of the researches takes on a globalizing way a vision of strong social and economic interaction, due to its transcendence and implications in the role played by the population and the landscape in the wildfire problems.

The current possibilities of the economic analysis supporting studies on the potential danger of forest ecosystems and the suppression difficulty operations based on fire behavior, represents an important advance in the decision making tools for fire management. Undoubtedly the incorporation of modern econometric tools based on efficiency and productivity concepts, as well as in the developing of utility functions, can help to carried out guidelines for the budgetary definition to support protection of ecosystems, considering the value of natural resources and the suppression costs.

The object of the present work is to carry out an methodological approach to modeling the productivity of forest fire extinction (or, suppression) operations. For this purpose it has been considered important to determine the structure and composition of the database made with the report of the forest fires occurred in a certain region, allow us to identify the variables that can provide consistent information in the econometric modeling of forest fires suppression productivity.

\section{Material and methods}

In the methodological approach, the deterministic determination of the suppression operational productivity evaluation option have been considered. For the development of this work, a total number of 20 fires were selected from the statistical forest fires database of the Andalucía Region (Spain) (table 1).

An updateable database of operations plans to fires extinction with the identification of behavior and influences of human factors, environmental conditions (scenarios of the events) and strategies suppression adopted, provides the information that gives access to past experiences, facilitating the sharing of knowledge at the level of capitalization and subsequent use of information in terms of the lessons learned, making possible the establishment of a "network of experience transmission " between the different people in charge of the forest fires management.

Table 1 - Relation and data base of the forest fires selected for this study

\begin{tabular}{|c|c|c|c|c|c|c|c|}
\hline $\begin{array}{c}\text { № } \\
\text { Wildfire }\end{array}$ & Date of ignition & Municiplity & $\begin{array}{c}\text { Total fire } \\
\text { perimeter } \\
(\mathrm{m})\end{array}$ & $\begin{array}{c}\text { Total } \\
\text { surface } \\
\text { (ha) }\end{array}$ & $\begin{array}{c}\text { Surface } \\
\text { contraction } \\
\text { factor FCS\% }\end{array}$ & $\begin{array}{c}\text { Time to } \\
\text { control } \\
\text { (min) }\end{array}$ & $\begin{array}{c}\text { Production } \\
\text { rate } \\
(\mathrm{m} / \mathrm{min})\end{array}$ \\
\hline 1 & 9 -ago-02 & MALAGA & 7355 & 120,5 & 11,14 & 1089 & 6,8 \\
\hline 2 & 22 -jul-06 & EL BURGO & 6456 & 110,54 & 0,56 & 1307 & 4,9 \\
\hline 3 & 9 -sept-03 & OJEN & 1467 & 14 & 13,79 & 1280 & 1,1 \\
\hline 4 & 9 -ago-05 & MALAGA & 3956 & 60,3 & 5,31 & 1010 & 3,9 \\
\hline 5 & 22 -ago-04 & FARAJAN & 3425 & 21 & 18,22 & 350 & 9,8 \\
\hline 6 & 26 -jul-02 & BENALMADENA & 1879 & 7 & 46,65 & 840 & 2,2 \\
\hline 7 & 20 -jun-02 & MALAGA & 1673 & 6,4 & 90,14 & 645 & 2,6 \\
\hline 8 & 2 -ago-04 & CORTES DE LA F. & 2819 & 17 & 24,91 & 750 & 3,8 \\
\hline 9 & 10 -oct-05 & ESTEPONA & 7349 & 69,9 & 14,34 & 1190 & 6,2 \\
\hline 10 & 9 -jul-06 & CASARES & 7768 & 99,9 & 12,46 & 200 & 38,8 \\
\hline 11 & 12 -ago-04 & COMPETA & 2965 & 17,9 & 87,71 & 215 & 13,8 \\
\hline 12 & 21 -ago-04 & GAUCIN & 3245 & 20 & 98,47 & 515 & 6,3 \\
\hline 13 & 14 -ago-04 & MIJAS & 3128 & 18,45 & 70,38 & 1418 & 2,2 \\
\hline 14 & 18 -ago-05 & CASARES & 5183 & 61,69 & 35,83 & 930 & 5,6 \\
\hline 15 & 4 -ago-06 & FRIGILIANA & 11234 & 210 & 77,35 & 1385 & 8,1 \\
\hline 16 & 3-ago-06 & CORTES DE LA F. & 7956 & 158,6 & 87,31 & 861 & 9,2 \\
\hline
\end{tabular}




\begin{tabular}{|c|c|c|c|c|c|c|c|}
17 & 7 -oct-06 & MARBELLA & 13489 & 457,33 & 45,14 & 780 & 17,3 \\
\hline 18 & 8-oct-06 & CORTES DE LA F. & 16781 & 602,1 & 74,85 & 1260 & 13,3 \\
\hline 19 & 16 -sept-06 & CASARES & 12689 & 320,66 & 55,72 & 774 & 16,4 \\
\hline 20 & 21 -sept-06 & CASARES & 14987 & 455 & 48,52 & 795 & 18,9 \\
\hline
\end{tabular}

The definition of the experience need previously of the investigation and reconstruction of the events (the wildfires), the analysis and the comprehension of the same, it allows to later extend the learned and recognized towards the capitalization of the experiences lived (Rodríguez y Silva,1999), (Rodríguez y Silva et al., 2007). From the generation of the database obtained through the capitalization, it is necessary to select the variables and parameters that will allow analyzing and evaluating the extinction operations productivity. The following should be considered:

- Fire perimeter controled by time unit (production rate) $(\mathrm{m} / \mathrm{min})$

- Surface contraction factor ACF, (understood as the rate calculated how the difference between one and the quotient between the real surface affected by the propagation of the fire and the surface obtained in free evolution, that is without extinction operations, subject to the time elapsed since the detection until the fire is controlled) (Rodríguez y Silva, 2007), (Rodríguez y Silva, and González-Cabán, 2010), (Rodríguez y Silva, and González Cabán, 2016)

- Average surface affected by each forest fire registered (ha / fire)

- Average extinction costs per affected area, $(€ /$ ha)

- Unitary costs of the differents resources to fires suppression

- Production rates of each differents resources

- Quotient between suppression cost and net change value of the natural resources

- List of the total resources despached to the fires, with special detail in the proportion of individual operations times in relation to the total sum of operational times of all resources involved in a fire.

- Factors related to suppression inefficiency causes, such as the difficulty of the extinction activities, adverse meteorological effects, simultaneity of fires ocurrence and WUI operational difficulties.

The database prepared for the development of the suppression production function, includes for each each of the 20 forest fires, the "Surface Contraction Factor (SFC)", (Rodríguez y Silva, 2007), (Rodríguez y Silva, and González-Cabán, 2010, 2016). This parameter is useful because it includes the control operational effects in the perimeter of the fire, as opposed to what would be the final result without carrying out extinction activity. The database was also expanded, incorporating how independent variables the meteorological danger indexes of the occurrence of forest fires (Rodríguez y Silva, 2002, 2004) and the suppression difficulty index (Rodríguez y Silva, et al., 2014), as well as the weighted extinction means mobilized for each fire disaggregated into ground resources and aerial resources.

\section{Deterministic model of suppression operational productivity}

The analysis of the productivity has been widely used in efficiency studies in many fields related to economics ((Aigner et al., 1977; Battese and Coelli, 1992, 1995; Greene, 2004; 2003; Hadri et al., 2003; Meeusen and Den Broeck, 1977). Likewise, functions have been modeled to provide information on the efficiency that can be achieved, depending on the effort applied in the resolution of emergencies or damage reduction., effects related to disturbances in natural resources (Huang et al., 2013; Penman et al., 2013; Grimsrud et al., 2008; Kovacs et al., 2014).

The background in the application of production functions in the modeling of actions aimed at defending against forest fires is reduced, among others, Holmes and Calkin of the analysis (2013), Katuwal et al. (2016). The research on efficiency under the approach of comparative analysis between the suppression costs and the economic value of natural resources saved (Molina et al. 2009; Rodríguez 
y Silva et al. 2009), provide important results that help qualify the utility of budgetary investments in defense against forest fires (Rodríguez y Silva and González-Cabán, 2016).

In this way the analytical process of the perimeter control fire productivity rate evaluation, under a deterministic model of the production function that can best predict operational performance is included below. The method used is to compare the results provided by two widely applied models in the econometric production function modeling, in the framework of the microeconomic analysis of business activities. The model functions selected are the Cobb-Douglas function and the CES function. The Cobb-Douglas production function $(\mathrm{CD}$, hereafter (1)) can be written as:

$$
Y=A \cdot x_{1}^{\alpha_{1}} \cdot x_{2}^{\alpha_{2}} \cdot \ldots \ldots \cdot x_{n}^{\alpha_{n}}
$$

The parameter A can be interpreted as a measure of technical efficiency of the productivity (that is, $\mathrm{A}=\mathrm{Ai}$ where the subscript $\mathrm{i}$ denotes the ith fire) since for any combination of inputs, the output increases with A. If the observations on which the function is defined are of time series and correspond to a certain sector, then A can be interpreted as an indicator of the state of the technology (in this case, A can be written as $A(t)$ where $t$ is the time variable) and its temporal variation as the effect of technical change about production (Álvarez Pinilla et al. 2003).

The Cobb-Douglas function is transformed into a linear multivariate function by taking logs, an extended form for the econometric resolution of the determination of the corresponding explanatory parameters of each of the independent variables, the transformed expression being the following (2):

$$
\operatorname{Ln} Y=\alpha_{0}+\alpha_{i} \sum_{1}^{i} \operatorname{Ln} x_{i}
$$

As an alternative and in order to overcome the rigidities of the Cobb-Douglas function, and in particular, that the elasticity of substitution is always equal to 1, Arrow, Chenery, Minhas and Solow (1961) introduced the CES function (Constant Elasticity of Substitution, that is, Constant Replacement Elasticity (3)) . This function for the case of two explanatory variables, can be expressed as follows:

$$
Y=A\left(\alpha \cdot x_{1}^{-\rho}+(1-\alpha) \cdot x_{2}^{-\rho}\right)^{-\eta / \rho}
$$

For the direct estimation of the production function, it is necessary to use non-linear regression analysis techniques. As a mathematical solution we can use a Taylor expansion around the value of $\rho$ $=0$, which gives us a functional approximation in neperian logarithms that adopts the following expression (4):

$$
\operatorname{Ln} Y=\operatorname{Ln}(A)+\eta \alpha \operatorname{Ln}\left(x_{1}\right)+\eta(1-\alpha) \operatorname{Ln}\left(x_{2}\right)-\rho \alpha \eta(1-\alpha)\left(\operatorname{Ln}\left(x_{1}\right)-\operatorname{Ln}\left(x_{2}\right)\right)^{2}
$$

Generalizing for (n) explanatory variables and making a change of parametric coefficients, the following expression is obtained (5):

$$
\operatorname{Ln} Y=\beta_{0}+\sum \beta_{i} \operatorname{Ln} x_{i}+\beta_{1+i}\left(\operatorname{Ln}\left(x_{1}\right)-\left(\sum \ln x_{1+i}\right)\right)^{2}
$$




\section{Results}

As indicated in the methodological section and in terms of the productivity analysis, we have been considered in addition, the surface contraction factor (SCF), the suppression difficulty index, and fire weather index. The incorporation of these variables of each fire, allowed to collect the meteorology effects in the different production functions developed in the framework of efficiency.

The Idex, represents the suppression difficulty index (simplified), calculated for the fire behavior average conditions of each wildfire. In its determination, the effects of heat per unit area caused by fire and flame length have been considered (Rodríguez y Silva et al., 2014). The IPMIF, represents the fire weather index of forest fire ocurrence occurrence (Rodríguez y Silva, 2002), (Rodríguez y Silva and Aguado, 2004).

RpMAR, represents the accounting of aerial resources number and type dispached to each wildfire, obtained through the weighting of the number of units and the factor of proportionality of the operation time for each one type in relation to the total suppression time spent of all aerial ressources. RpMT, represents the accounting of ground resources number and type dispached to each wildfire, obtained through the weighting of the number of units and the factor of proportionality of the operation time for each one type in relation to the total suppression time spent of all ground ressources. Fcs\%, represents the surface contraction factor $(\mathrm{FCs} \%=\mathrm{SCF})$.

The independent variables considered to evaluate the deterministic function of suppression operational productivity, such as the perimeter length controlled per unit of time $(\mathrm{m} / \mathrm{min})$, are the following (table 2) :

Table 2 - Variables considered to develop the deterministic models

$\begin{array}{cccc}\text { Aerial resources } & \text { Ground resources } & \text { Suppression } & \text { Fire weather } \\ \text { suppression effect } & \text { suppression effect } & \text { Difficulty } & \text { index } \\ \text { Rp MAR } & \text { Rp MT } & \text { Index (Idex) } & \text { IPMIF }\end{array}$

The table elaborated for the modeling of the suppression operations productions, allows to compare the results of each one of the variables considered for the twenty fires analyzed (table 3 ).

Table 3 - Values of the variables considered to develop the deterministic models

\begin{tabular}{|c|c|c|c|c|c|}
\hline $\begin{array}{c}\text { № } \\
\text { wildfire }\end{array}$ & $\begin{array}{l}\text { Control fire } \\
\text { perimeter } \\
\text { production } \\
\text { rate } \mathrm{m} / \mathrm{min}(\mathrm{Y})\end{array}$ & Rp MAR & Rp MT & Idex & IPMIF \\
\hline 1 & 6,75 & 11,51 & 37,28 & 6,49 & 228,31 \\
\hline 2 & 4,93 & 8,34 & 37,38 & 6,46 & 188,31 \\
\hline 3 & 1,14 & 15,55 & 59,93 & 5,25 & 131,52 \\
\hline 4 & 3,91 & 19,32 & 48,23 & 6,28 & 171,07 \\
\hline 5 & 9,78 & 31,65 & 39,35 & 5,59 & 149,13 \\
\hline 6 & 2,23 & 17,83 & 34,92 & 5,38 & 133,42 \\
\hline 7 & 2,59 & 18,91 & 33,53 & 4,87 & 128,86 \\
\hline 8 & 3,75 & 14,13 & 29,64 & 6,05 & 158,8 \\
\hline 9 & 6,17 & 29,16 & 45,77 & 6,45 & 187,84 \\
\hline 10 & 38,84 & 62,98 & 79,72 & 6,58 & 209,83 \\
\hline 11 & 13,79 & 52,25 & 84,65 & 6,25 & 160,1 \\
\hline 12 & 6,30 & 34,00 & 73,07 & 6,28 & 169,1 \\
\hline 13 & 2,20 & 10,48 & 55,02 & 6,31 & 178,56 \\
\hline 14 & 5,57 & 14,20 & 45,71 & 6,63 & 209,83 \\
\hline 15 & 8,11 & 36,78 & 39,7 & 6,78 & 295,08 \\
\hline 16 & 9,24 & 32,55 & 43,74 & 6,59 & 252,48 \\
\hline
\end{tabular}




$\begin{array}{llllll}17 & 17,29 & 36,77 & 43,79 & 7,35 & 380,73 \\ 18 & 13,31 & 35,05 & 52,71 & 8,12 & 420,89 \\ 19 & 16,39 & 10,22 & 41,79 & 7,86 & 318,41 \\ 20 & 18,85 & 29,80 & 48,62 & 7,14 & 361,89\end{array}$

The production function of the suppression activities determined with the structure and econometric composition of the Cobb-Douglas function, has been estimated as follows (table 4):

$$
\begin{aligned}
& \ln y=-3.15+0.881 * \ln x_{1}-0.360 * \ln x_{2}+5.18 * \ln x_{3}-0.336 * \ln x_{4} \\
& \left.\begin{array}{llll}
(1.06) & (0.299) & (0.562) & (2.48)
\end{array}\right] \\
& \mathrm{n}=20, \mathrm{R}^{2}=0.739
\end{aligned}
$$

Table 4. Model 1 (Cobb-Douglas): MCO, using observations 1-20

$\begin{array}{lccccc} & \text { Coeficients } & \text { Desv. stand. } & t & p \text { value } & \\ \text { const } & -3.1524 & 1.05775 & -2.9803 & 0.0093 & * * * \\ \ln (\mathrm{Rp} & 0.880821 & 0.298649 & 2.9494 & 0.0099 & * * * \\ \text { MAR) } & & & & & \\ \ln (\mathrm{Rp} \text { MT) } & -0.359546 & 0.561508 & -0.6403 & 0.5316 & \\ \ln (\mathrm{Idex}) & 5.18219 & 2.47994 & 2.0896 & 0.0541 & * \\ \ln (\mathrm{IPMIF}) & -0.33553 & 0.817756 & -0.4103 & 0.6874 & \end{array}$

$\begin{array}{lrlr}\text { Mean of vble. dep. } & 0.832020 & \text { D.T. vble. dep. } & 0.377385 \\ \text { Sum squard w. } & 0.706283 & \text { D.T. of the regresion } & 0.216992 \\ \mathrm{R}^{2} & 0.738990 & \mathrm{R}^{2} \text { adjusted } & 0.669388 \\ \mathrm{~F}(4,15) & 8.503972 & \text { P value (of F) } & 0.000863 \\ \text { Log- likelihood } & 5.055939 & \text { Akaike criteria } & -0.111879 \\ \text { Schwarz criteria } & 4.866783 & \text { Hannan-Quinn criteria } & 0.860008\end{array}$

The production function of the suppression activities determined with the structure and econometric composition of the CES function, has been estimated as follows (table 5):

$$
\begin{gathered}
\ln y=13.3+10.8 * \ln x_{1}-9.99 * \ln x_{2}-5.17 * \ln x_{3}-9.95 * \ln x_{4}+1.42^{*} x_{5} \\
(3.30)(2.18)
\end{gathered}
$$

The variable $\mathrm{x}_{5}$, is following the equation $(5)=\left(\ln \mathrm{x}_{1}-\left(\ln \mathrm{x}_{2}+\ln \mathrm{x}_{3}+\ln \mathrm{x}_{4}\right)\right)^{2}$

$$
\mathrm{n}=20, \mathrm{R}^{2}=0.813
$$


Table 5 - Model 2 (CES): MCO, using observations 1-20

\begin{tabular}{|c|c|c|c|c|}
\hline & Coeficients & Desv. Stan. & $t$ & $p$-value \\
\hline const & 13.3182 & 3.29606 & 4.0407 & 0.0012 \\
\hline $\ln (\mathrm{Rp} \mathrm{MAR})$ & 10.7661 & 2.18035 & 4.9378 & 0.0002 \\
\hline $\ln (\mathrm{Rp} \mathrm{MT})$ & -9.98696 & 2.00213 & -4.9882 & 0.0002 \\
\hline $\ln (\operatorname{Idex})$ & -5.16911 & 2.32676 & -2.2216 & 0.0433 \\
\hline $\ln (\mathrm{IPMIF})$ & -9.95401 & 2.27882 & -4.3681 & 0.0006 \\
\hline $\begin{array}{c}(\ln (\mathrm{RpMAR})- \\
(\operatorname{lnRpMT}+\ln (\operatorname{Idex})+\ln (\mathrm{IPMIF}))^{2}\end{array}$ & 1.41696 & 0.293173 & 4.8332 & 0.0003 \\
\hline Mean of vble. dep. & 0.832020 & \multicolumn{2}{|c|}{ D.T. of vable. dep. } & 0.377385 \\
\hline Sum squard w. & 0.505963 & \multicolumn{2}{|c|}{ D.T. of regresion } & 0.190106 \\
\hline $\mathrm{R}^{2}$ & 0.813019 & \multicolumn{2}{|c|}{$\mathrm{R}^{2}$ adjusted } & 0.746241 \\
\hline $\mathrm{F}(5,14)$ & 10.12371 & \multicolumn{2}{|c|}{$\mathrm{p}$ value $(\mathrm{F})$} & 0.000291 \\
\hline Log- likelihood & 8.391472 & \multicolumn{2}{|c|}{ Akaike criteria } & -4.782945 \\
\hline Schwarz criteria & 1.191449 & \multicolumn{2}{|c|}{ Hannan-Quinn criteria } & -3.616681 \\
\hline
\end{tabular}

\section{Discussion}

The study and analysis of the operational results complements the experience and knowledge of firefighting professionals. The monitoring of the operational sequences in the achievement of the objectives included in the attack plans allows us to monitor the results achieved and identify those other objectives that could not be achieved. The collection of variables and the behavior maintained by them during extinction operations provides a starting point to evaluate the causes that could limit the suppresion actions.

The modeling of fire suppression production functions represents a potentially useful tool to support the preparation of operational suppression plans. The methodological approach presents a comparative analysis of two production functions: the Cobb-Douglas production function and a second model following the characteristics of the Constant Elasticity of Substitution (CES) production function.

The comparison suggests that the CES model has greater predictive accuracy than the CobbDouglas model. The CES model has an adjusted coefficient of determination (adjusted $\mathrm{R}^{2}$ ) of 0.74 , compared to 0.66 corresponding to the Cobb-Douglas model. Likewise, the values obtained for the Akaike, Schwarz and Hannan-Quinn criteria of the CES function are lower than those obtained for the Cobb-Douglas function.

This method offers a promising approach for developing explanatory models of wildfire suppression efforts. Combining variables in a production model to provide information on factors that offer sufficient predictive ability can indicate the production capacity provided by a specific combination of trained teams for the extinction of forest fires.

\section{Conclusions}

The application of efficiency and productivity analysis tools is a new opportunity to study wildfire suppression operations. This provides the possibility of reducing operational uncertainty in order to obtain reliable information to support the selection and combination of extinction means according to 
operational scenarios. Improvements in suppression planning based on the production analysis presented in this paper can inform efforts to reducethe costs of wildfire suppression and net change in value of the natural resources affected by wildfires.

\section{Acknowledgements}

The authors express their gratitude to the GEPRIF project (RTA2014-00011-C06-01), and to the VIS4FIRE project (RTA2017-00042-C05-04), funded by the National Institute for Agricultural, Food Research and Technology (INIA). Likewise, they express their gratitude to the INFOCA Plan management of the Junta de Andalucía (Ministry of Environment and Territory Planning), for the access to the databases and the support in the field monitoring and research work that have been necessary to achieve the objectives of this work.

\section{References}

Aigner, D., Lovell, C., Schmidt, P (1977). Formulation and estimation of stochastic frontier production function models. J. Econ. 6, 21e37.

Alvarez Pinilla A., Arias Sampedro C., Orea Sánchez 1 (2003). Introducción al análisis empírico de la producción. Universidad de Oviedo y Universidad de León.

Arrow K., Chenery H., MInhas B., Solow R (1961). Labor Substitution and Economics Efficiency. The Reviw of Economics and Statistics. Vol 43, No 43.

Battese G, Coelli T (1992). Frontier Production Functions, Technical Efficiency and Panel Data: with Application to Paddy Farmers in India. Journal of Productivity Analysis 3(1-2): 153-169.

Battese, G.E., Coelli, T.J 1(995). A model for technical inefficiency effects in a stochastic frontier production function for panel data. Empir. Econ. 20, 325e332

Greene, W., 2003. Econometric Analysis. Prentice Hall, Upper Saddle River, New Jersey

Greene, W., 2004. Distinguishing between heterogeneity and inefficiency: stochastic frontier analysis of the World Health Organization's panel data on national health care systems. Health Econ. 13, $959 \mathrm{e} 980$.

Grimsrud, K.M., Chermak, J.M., Hansen, J., Thacher, J.A., Krause, K (2008). A twoagent dynamic model with an invasive weed diffusion externality: an application to Yellow Starthistle (Centaurea solstitialis L.) in New Mexico. J. Environ. Manag. 89, $322 \mathrm{e} 335$.

Hadri, K., Guermat, C., Whittaker, J., 2003. Estimation of technical inefficiency effects using panel data and doubly heteroscedastic stochastic production frontiers. Empir. Econ. 28, 203e222.

Holmes, T.P., Calkin, D.E (2013). Econometric analysis of fire suppression production functions for large wildland fires. International Journal of Wildland Fire 22, $246 \mathrm{e} 255$.

Huang, C.-H., Finkral, A., Sorensen, C., Kolb, T (2013). Toward full economic valuation of forest fuels-reduction treatments. Journal of Environmental Management. 130, $221 \mathrm{e} 231$.

Katuwal H., Calkin D., Hand M (2016). Production and efficiency of large wildland fire suppression effort: A stochastic frontier analysis. Journal of Environmental Management 166 (2016) 227-236. http://dx.doi.org/10.1016/j.jenvman.2015.10

Kovacs, K.F., Haight, R.G., Mercader, R.J., McCullough, D.G (2014). A bioeconomic analysis of an emerald ash borer invasion of an urban forest with multiple jurisdictions. Resour. Energy Econ. 36, $270 \mathrm{e} 289$.

Meeusen, W., Den Broeck, J. Van (1977). Efficiency estimation from Cobb-Douglas production functions with composed error. Int. Econ. Rev. 18, 435e444. 
Molina J.R.; Rodríguez y Silva F.; Herrera M.A.: Zamora R (2009). A simulation tool for socioeconomic planning on forest fire supression management. Libro Forest Fires: Detection, Supresión and Prevention. Nova Science Publishers. USA.

Penman, T., Collins, L., Price, O., Bradstock, R., Metcalf, S., Chong, D. (2013). Examining the relative effects of fire weather, suppression and fuel treatment on fire behaviour. A simulation study. J. Environ. Manag. 131, 325e333.

Rodríguez y Silva F (2002). Visual Forest Fire Weather Index (VVFFWI) a mathematical model for the prediction of forest fires weather danger in Mediterranean ecosystems. IV Conference on Forest Fire Research. Luso. ADAI.

Rodríguez y Silva, F., Aguado I (2004). El factor meteorológico en los incendios forestales. En nuevas tecnologías para la estimación del riesgo de incendios forestales. Editores: Emilio Chuvieco Salinero y María del Pilar Martín Isabel. Colección de Estudios Ambientales y Socioeconómicos. Consejo Superior de Investigaciones Científicas. Madrid.

Rodríguez y Silva, F (2005). Sinami, un método para el análisis económico de los planes de defensa contra incendios forestales mediterráneos, desarrollo de una aplicación desde una perspectiva provincial. $4^{\circ}$ Congreso Forestal Español. La ciencia forestal: respuesta para la sostenibilidad. Sociedad Española de Ciencias Forestales. Junta de Andalucía. Gobierno de Aragón. Zaragoza.

Rodríguez y Silva F., Molina Martínez J.R., Rodríguez Leal J (2014). The efficiency analysis of the fire control operations using the VISUAL-SEVEIF tool. Chapter 7 - Social and Economic Issues. Advances in Forest Fire Research http://dx.doi.org/10.14195/978-989-26-0884-6_210

Rodríguez y Silva, F., Molina Martínez J.R., González-Cabán A (2014). A methodology for determining operational priorities for prevention and suppression of wildland fires. 'International Journal of Wildland Fire . http://dx.doi.org/10.1071/WF13063

Rodriguez y Silva, F (1999). A forest fire simulation tool for economic planning in fire suppression management models: an application of the Arcar-Cardin. Proceedings of the Symposium on Fire Economics, Planning and Policy: Bottom lines, USDA Forest Service. Pacific Southwest Research Station. General Technical Report PSW-GTR-173. San Diego California.

Rodríguez y Silva, F. Molina JR. Herrera M. Zamora R (2007). Vulnerabilidad socioeconómica de los espacios forestales frente al impacto de los incendios, aproximación metodológica mediante sistemas de información geográficos (proyecto Firemap). IV International Wildland Fire Conference. Proceedings. Sevilla. (www.wildfire07.es).

Rodríguez y Silva F., MolinA J.R., Herrera M.A., Zamora R (2009). The impact of fire and the socioeconomic vulnerability of forest ecosystems: A methodological approach using remote sensing and geographical information systems. General Technical Report PSW-GTR-227. Pacific Southwest Research Station. Forest Service, U.S. Department of Agriculture; 151 - 168.

Rodríguez y Silva F. ;, González-Cabán A (2010). "SINAMI": a tool for the economic evaluation of forest fire management programs in Mediterranean ecosystems. International Journal of Wildland Fire 19: 927-936.

Rodríguez y Silva F.; González-Cabán A (2016). Contribution of suppression difficulty and lessons learned in forecasting fire suppression operations productivity: a methodological approach. Journal of Forest Economics. DOI: http://dx.doi.org/10.1016/j.jfe.2016.10.002 